\title{
PERSONALITY SPEECH DIAGNOSTICS IN AUTHOR IDENTIFICATION BASED ON GENDER PARAMETER: QUANTITATIVE APPROACH
}

\author{
Svetlana V. Ionova \\ Pushkin State Russian Language Institute, Moscow, Russia; \\ Moscow Research Center, Moscow, Russia \\ Igor V. Ogorelkov \\ Moscow Research Center, Moscow, Russia
}

\begin{abstract}
The article discusses the issues of conducting authorship diagnostic studies in order to identify the gender of the anonymous text author. The concept of gender is considered as a conventional social construct, comprising the ideas about culturally conditioned model of masculinity or femininity, which are currently accepted by Russian society. The corpus of more than 1000 written texts of mainly political discourse, written by people with different gender affiliations, serves as the material that enables to justify the possibility of application quantitative analysis method, based on frequency characteristics of semantically independent words, belonging to lexical-andgrammatical classes of words: pronouns, particles, prepositions, conjunctions and parenthesis. The method under consideration is aimed at identification and analyzing unevident implied signs, which can't be revealed whilst superficial analysis. Frequent, persistent occurrence of these signs in the texts of political discourse enables to regard them as highly informative quantitative characteristics of written speech of the authors belonging to different gender groups. It is stated, the results of application the quantitative model of author's gender identification, represented in the paper, are more reliable if they are used in combination with traditional linguistic model, which presupposes the analysis of linguistic, speech, textual, semantic, psycholinguistic and social characteristics of texts. The article outlines the prospects of speech diagnostics of a person on the basis of gender for the development of author's forensic examination.

Key words: linguistics diagnostics, auto-analysis, speech skills, speech behavior, signs of written speech, quantitative model of gender, forensic examination.

Citation. Ionova S.V., Ogorelkov I.V. Personality Speech Diagnostics in Author Identification Based on Gender Parameter: Quantitative Approach. Vestnik Volgogradskogo gosudarstvennogo universiteta. Seriya 2. Yazykoznanie [Science Journal of Volgograd State University. Linguistics], 2020, vol. 19, no. 1, pp. 115-127. (in Russian). DOI: https://doi.org/10.15688/jvolsu2.2020.1.10
\end{abstract}

\section{РЕЧЕВАЯ ДИАГНОСТИКА ЛИЧНОСТИ ПО ГЕНДЕРНОМУ ПРИЗНАКУ В АВТОРОВЕДЕНИИ: КВАНТИТАТИВНЫЙ ПОДХОД}

\author{
Светлана Валентиновна Ионова \\ Государственный институт русского языка им. А.С. Пушкина, г. Москва, Россия; \\ Московский исследовательский центр, г. Москва, Россия
}

Игорь Витальевич Огорелков

Московский исследовательский центр, г. Москва, Россия

Аннотация. В статье рассматриваются вопросы проведения автороведческих диагностических исследований с целью выявления гендерной принадлежности автора анонимного текста. Гендер понимается как 
социальный конструкт, в котором аккумулированы представления о культурно обусловленной модели мужественности или женственности в современном российском обществе. На материале корпуса письменных текстов политического дискурса (более 1000 объектов), написанных лицами различной гендерной принадлежности, обосновывается возможность применения квантитативного метода анализа, основанного на частотных характеристиках семантически независимых слов лексико-грамматических классов местоимений, частиц, предлогов, союзов и вводных слов. Этот метод направлен на поиск и изучение неочевидных и скрытых от поверхностного наблюдения признаков, частотность, устойчивость и повторяемость которых в массиве текстов политического дискурса позволяет рассматривать их в качестве высокоинформативных квантитативных признаков письменной речи авторов, принадлежащих к разным гендерным группам. Повышение надежности результатов применения квантитативной модели гендера, выявленной в данном исследовании, предполагает ее сочетание с традиционной лингвистической моделью, включающей анализ языковых, речевых, текстовых, смысловых, психолингвистических и социальных характеристик текстов. В статье намечаются перспективы речевой диагностики личности по гендерному признаку в автороведческой экспертизе.

Ключевые слова: лингвистическая диагностика, автороведение, речемыслительный навык, речевое поведение, признаки письменной речи, квантитативная модель гендера, судебная экспертиза.

Цитирование. Ионова С. В., Огорелков И. В. Речевая диагностика личности по гендерному признаку в автороведении: квантитативный подход // Вестник Волгоградского государственного университета. Серия 2, Языкознание. - 2020. - Т. 19, № 1. - С. 115-127. - DOI: https://doi.org/10.15688/jvolsu2.2020.1.10

\section{Введение}

Гендерный дискурс составляет неотъемлемую часть глобального культурного дискурса. Он определяет грамматику и стилистику речи, тенденции словоупотребления и смыслопостроения текстов, с концептуальной точки зрения «акцентирует социально-культурную, а не природную доминанту пола» [Кирилина, 1999, с. 27]. Гендер является имманентным качеством языковой личности и может находить отражение в ее коммуникативном поведении и письменных речевых произведениях (А.В. Артемова, В.В. Ганина, М.Д. Городникова, Е.И. Горошко, А.А. Григорян, Е.С. Гриценко, Г.С. Двинянинова, И.В. Зыкова, Ф.И. Карташкова, А.В. Кирилина, Г.Е. Крейдлин, Д.Ч. Малишевская, Е.В. Милосердова, Л.В. Полубиченко, И.Г. Серова, Г.Г. Слышкин, И.А. Стернин, С.К. Табурова, Ф.Ф. Фатыхова и др.). В связи с этим данный аспект языка в филологии становится предметом диагностических исследований, посвященных атрибуции текстов (см. словари писателей: [Словарь языка Достоевского, 2001; Словарь языка Пушкина, 2000], выявлению специфики идиостиля их авторов, способов речевой идентификации, а также симуляции и речевой имитации в художественных [Гречушникова, 2000; Иванченко, 2008] или криминальных целях [Ионова, 2014; Кузниченко, 2004; Потапова, 2001].

С начальных этапов существования гендерная лингвистика имела ярко выраженную практическую направленность. При этом значительное количество научных трудов было связано с потребностями криминалистической автороведческой экспертизы [Вул, Мартынюк, 1987; Гомон, 1990; Мартынюк, Землянский, 1994], ставящей своей целью выявление диагностических показателей гендерной принадлежности речевого произведения, оптимизации методики определения пола (гендера) автора анонимного (псевдонимного) текста.

Автороведческая диагностическая экспертиза считается одним из видов традиционных криминалистических экспертиз. Она опирается на систему знаний о закономерностях и условиях речевого поведения человека, проявления его речемыслительного навыка [Комплексная методика..., 2007]. Предмет изучения диагностической экспертизы составляют характер речи автора (индивидуальный или групповой), ее динамическая устойчивость и вариативность, методы установления авторства анонимного (псевдонимного) текста, возможности составления нескольких текстов (или их фрагментов) одним лицом, влияния третьих лиц на авторский стиль текста [Методические рекомендации..., 2015]. В качестве объектов исследования выступают письменные тексты, в которых устанавливаются диагностические признаки социально-биографических характеристик автора, в частности пол (гендер). Гендерные признаки автора выступают важным диагностическим показателем, позволяющим определять речевые произведения, типичные 
для групп носителей языка, выделяемых по социально-половой принадлежности и представляющих собой совокупность языковых (формальных и смысловых), текстолингвистических, психолингвистических показателей в том или ином частотном выражении [Криминалистика..., 1987]. Диагностические показатели гендерных особенностей речи являются востребованными при решении задач об имитации стиля и основываются на комплексе броских, часто встречающихся и легко поддающихся имитации классификационных признаков (идентификационных характеристик) женской и мужской речи [Гомон, 1990, с. 96].

\section{Проблематика исследования}

Гендер в лингвистике относится к числу наиболее дискуссионных категорий и трактуется как мыслительный конструкт, модель описания проблем пола и разграничения его биологических и социокультурных функций, а также социальный конструкт, создаваемый обществом, в том числе и посредством языка [Григорян, 2004].

Значительное число научных исследований в отечественной и зарубежной лингвистике демонстрирует, что признаки социального пола маркируются индексально и облигаторно в морфологии многих языков [Сепир, 1993]; европейские языки в своей структуре андроцентричны и отражают мужскую картину мира [Lakoff, 1973], при этом женское предстает главным образом в виде признаков «чужого» или вообще игнорируется; пол носителей языка определенным образом влияет на языковую перформацию [Jespersen, 1998; Labov, 1971; Trudgill, 1972]; вербальное и невербальное коммуникативное поведение человека имеет гендерную специфику [Горошко, 1999; Горошко, Павлова, 2015; Крейдлин, 2003; Стернин, 2001; Табурова, 2000], гендерные стереотипы находят отражение в языковом сознании носителей языка [Кирилина, 1999; 2015; Ощепкова, 2003; Уфимцева, 2018]. Эти и другие выводы ученых позволяют заключить, что фемининность и маскулинность в лингвистическом представлении резко разграничены и противопоставлены друг другу в качественном (положительная и отрицательная оценка) и количественном (доминирова- ние мужского как общечеловеческого) отношении, что ведет к образованию гендерной асимметрии. С учетом данного тезиса возможность выделения набора дистинктивных признаков гендера в языке, обоснованная в трудах лингвистов, психолингвистов, социологов, лингвокультурологов и антропологов, становится объективной.

В то же время гендерные концепции в языкознании традиционно считаются наиболее уязвимыми в плане их практической верификации и теоретической двойственности, поскольку «непроходимых» границ между мужской и женской речью в русском языке не существует [Кирилина, 1999]. Е.И. Горошко в своем экспериментальном исследовании свободных ассоциаций показала, что гендерные различия во многом нейтрализуются в речи лиц, близких по социальному статусу (например, лиц с высшим образованием, занятых интеллектуальной деятельностью) [Горошко, 1998]. Установлено, что доминирующая мужественность и доминирующая женственность меняются от культуры к культуре и должны определяться как динамические, исторически изменчивые концепты [Connell, 1993; Pollack, 1995; Rogoff, Leer, 1993; Wann ist der Mann ein Mann..., 1997], своеобразный «семиотический коллаж», в котором обнаруживаются различные составляющие, относящиеся к той или иной культуре или историческому периоду [Степанов, 1997].

Современные исследования показывают, что актуальность выражаемых гендерных признаков в языке (см. их подробное описание в работе [Земская, Китайгородская, Розанова, 1993]), являющихся важнейшими для обоснования возможности дифференциации его социальных вариантов, усиливается или ослабевает в зависимости от меняющихся условий жизни, и поэтому они должны рассматриваться как тенденции употребления, симптомы первого и второго порядка [Земская, Китайгородская, Розанова, 1993]. Так, наряду с существовавшей издавна тенденцией к нейтрализации пола и игнорированию женскости в XXI в. в современном языке «обнаруживается своеобразный "грамматический вирус" женскости: публицистический дискурс предпочитает обозначать лиц женского пола по тому или иному виду деятельности с по- 
мощью номинаций с суффиксами женскости, прежде всего с суффиксом -ш(а), например: банкирша, министерша, президентша и др.» [Вепрева, 2010, с. 74]. Стереотипное представление о речи мужчин (четкая логика, лаконичность изложения, последовательность, конкретность, предметность в изложении фактов, событий, аргументированность, обоснованность изложения [Жельвис 1997; Connell, 1993; Pollack, 1995]) и женщин (уменьшительные суффиксы, косвенные речевые акты, формы вежливости и смягчения, отсутствие черт доминантности, признаки кооперативной коммуникации [Мартынюк, Землянский, 1994]) в связи с появлением понятий не-бинарных личностей и концепции гендерной нейтрализации языка сегодня трансформируется и требует поиска новых лингвистических делимитаторов гендера. Последние должны способствовать также решению задачи разграничения индивидуальных (речь конкретного человека) и групповых (биологических, социальных) речевых черт [Сиротинина, 1996, с. 4], определения лингвистических маркеров, связанных с особенностями психического склада, характера, профессии человека, его роли в социуме и различием по полу [Земская, Китайгородская, Розанова, 1993, с. 132].

Дискуссионные вопросы гендерной лингвистики в отношении к письменным речевым произведениям показывают, что существующие лингвистические методы диагностирования гендера находятся в прямой зависимости от множества факторов, значимых для построения текстов их авторами: характера национальной культуры, социального статуса лица, его образования, уровня языковой, текстовой и коммуникативной компетенций, жанра и тематики создаваемого речевого произведения, индивидуального стиля и др. В связи с этим выдвинем в качестве гипотезы предположение о том, что дифференцирующие гендерные признаки автора текста возможно установить при выполнении следующих условий: 1) наличие единых дискурсивных условий и типов текстов, создаваемых авторами, в которых иные социокультурные факторы (кроме гендера) были бы максимально нейтрализованы; 2) рассмотрение способов языкового употребления в текстах представителей гендерных групп на уровне тематически независимых единиц.

\section{Материал и методика исследования}

В качестве материала исследования использованы письменные тексты политического дискурса, понимаемого как «совокупность тематически соотнесенных» [Чернявская, 2001, с. 14-16] текстов разных жанров, а также процесс создания, трансляции и оборота политической информации, участниками которого становятся все, кто с ее помощью выражают свое мнение и обсуждают «смысл и значение сообщений, касающихся проведения государственной политики» [Perloff, 1998, с. 8].

Письменный язык политики направлен на соблюдение и поддержание языковой нормативности, мотивированной различными социальными, политическими и коммерческими потребностями и ориентированной на поддержание представления о том, каким должно быть речевое поведение политического лица [Milroy, Milroy, 1985, с. 23]. Для овладения стандартным вариантом авторам текстов требуется наличие определенного коммуникативного бэкграунда, указывающего на принадлежность к определенному социальному классу [Ervin-Tripp, 1972; Fairclough, 2003; Ochs, 1979].

Выделяемые в судебном автороведении признаки мужской и женской речи [Гомон, 1990, c. 96], которые в бытовом дискурсе подчиняются принципу гендерного позиционирования, в письменном политическом дискурсе часто не имеют уверенной дифференциации, хотя стилевые различия между мужскими и женскими политическими текстами ощущаются читателями и исследователями политического языка [Куницына, 2011], несмотря на существующее стремление авторов к гендерной нейтрализации. Сравним тексты 1 и 2, приведенные ниже:

\section{Текст 1.}

Непонятно, кто с кем борется? Власть с оппозицией? Но в результате последние только набирают. Любой порядочный человек после таких наездов выйдет на улицу. Не сейчас - так позже. Получается, власть сама лодку и качает. Или внутри власти - конфликт кланов и одна из сторон использует грубую силу устрашения для укрепления своих позиций? Москва становится ареной все более скандальной борьбы каких сторон? (Хакамада И. Борьба за власть: кого с кем?// Эхо Москвы: блог 2012. 17 июня). 
Текст 2.

Ну, так вот - никто из этих, крайне немногочисленных для огромной страны, людей не удосужился доказать «граду и миру», что обсуждаемый ими процесс действительно является кризисом. А если это не кризис, а коллапс? Или катастрофа? Серьезные люди вместо того, чтобы ввести понятие, сопоставить его с другими понятиями, доказать корректность применения определенного понятия к происходящему, - сходу пишут (в подавляющем большинстве случаев): «Поскольку мы имеем дело с кризисом, то...» (Кургинян С.И. Кризис и другие (О грозящей катастрофе) // Завтра. 2009. 11 февраля (№ 7)).

В рассматриваемых примерах видно, что политические тексты, написанные И. Хакамада и С. Кургиняном, не имеют явных гендерных различий, соответствующих стереотипным представлениям о речевом поведении мужчин и женщин [Гомон, 1990; Земская, Китайгородская, Розанова, 1993; Кирилина, Томская, 2005]. Однако неявно они воспринимаются как гендерно маркированные, что обосновывает важность поиска и изучения неочевидных и скрытых от поверхностного наблюдения признаков. В условиях медиатизации политического дискурса следует учитывать также факт возможного написания текста специалистами в сфере медиа и спичрайта от имени политика, который при этом «берет на себя ответственность за его содержание» [Чудинов, 2012, с. 54], в том числе соглашаясь с формой его гендерного позиционирования.

Материалом для создания методики в данном исследовании послужили письменные русскоязычные тексты политического дискурса (авторов мужчин и женщин), размещенные в открытом доступе на сайтах сети Интернет. Общий корпус анализируемых текстов составил 1000 авторских текстов объемом более 8000 словоупотреблений каждый (общий объем - 9710541 словоупотреблений); из них - корпусы 500 «мужских» и 500 «женских» текстов. В числе авторов имена известных участников политического дискурса: Ксения Собчак, Мария Захарова, Мария Гайдар, Ирина Хакамада, Лидия Графова, Георгий Сатаров, Илья Яшин, Константин Боровой, Гарри Каспаров, Сергей Митрохин, Александр Невзо- ров, Алексей Венедиктов, Матвей Ганапольский и др.

На предварительном этапе исследования был проведен частотный анализ употребления слов изучаемых текстов, не зависящих семантически от его тематики и содержательных особенностей. Отбор таких слов позволил исключить из анализа знаменательные части речи с выраженным лексическим и грамматическим значением, а также слова с низкой частотностью употребления. В качестве выявленных единиц, отвечающих заданным критериям, в дальнейшей работе использовались частотные выражения и слова лексико-грамматических классов: личные, притяжательные, указательные, отрицательные, неопределенные местоимения; сочинительные и подчинительные союзы; простые и производные предлоги; частиu̧ь; вводные слова. Возможность использования в лингвистическом анализе данных классов слов без учета семантики слов и предложений основывается на возможности выделения разных лексико-грамматических классов слов с позиций наличия / отсутствия номинативности [Кубрякова, 1978, с. 114], а также положении о морфологической реализации на поверхностном уровне высказывания глубинной грамматики, передающей логику сообщения [Филлмор, 1981, с. 372-374].

Относительная частота употребления (соотношение количества слов и количества употреблений различных их форм) представленных лексико-грамматических классов слов в письменных русскоязычных текстах политического дискурса была установлена с помощью специализированного программного обеспечения TextAnalyst 2.0., позволяющего автоматизировать обработку большого массива данных. В результате анализа корпуса русскоязычных текстов политического дискурса был выявлен комплекс частотных лингвистических маркеров, с высокой степенью вероятности определяющих гендер авторов. Для каждого из маркеров был вычислен порог частотности, который рассчитывался по формуле: «число вхождений / объем корпуса (в словоформах)». Объем женского корпуса составил 4551389 словоупотреблений, мужского - 5159152 словоупотребления. 


\section{Результаты и обсуждение}

На этапе первичной обработки текстового массива были определены частотные индексы использования различных лексикограмматических классов слов (местоимений, частиц, предлогов, союзов и вводных слов) отдельно для «мужских» и «женских» корпусов письменных русскоязычных текстов политического дискурса (см. пример индексации в таблице).

Отраженный в таблице пример соотношения частотных индексов сочинительных союзов в «мужских» и «женских» текстах политического дискурса, а также комплекс показателей иных групп индексов позволили установить, что маркерами письменной речи мужчин в исследуемом текстовом массиве являются союзы но, как, если, или, кто, частицы не, нет, уже, местоимения этот, такой; женщин - союзы тоже, также; предлоги $в, u з, \kappa, n o, o, c$; местоимения я, он. Вводные слова в числе различительных маркеров мужской и женской речи не используются. В отличие от лексико-семантических, смысловых, текстовых признаков указанные маркеры отражают скрытые и неочевидные закономерности употребления языка гендерными группами авторов. Они в минимальной степени могут рефлексироваться пишушим и подвергаться сознательным стилистическим и иным преобразованиям. Следовательно, в отличие от семантически нагруженных элемен- тов высказываний выявленные маркеры способны отразить регулярные употребления единиц языка в текстах без учета предпочтений авторов в выборе. Частотность, устойчивость и повторяемость указанных маркеров в массиве текстов авторов, принадлежащих к разным гендерным группам, позволяет рассматривать их в качестве высокоинформативных квантитативных признаков письменной речи авторов политических текстов.

На рисунках разными цветами выделены количественные характеристики лингвистических признаков «мужских» и «женских» текстов, демонстрирующие наличие разных индексов частотности для групп анализируемых единиц: союза но (см. рис. 1) и предлога из (см. рис. 2).

Значительный массив исследованных текстов свидетельствует о том, что частотные показатели маркеров в них всегда имеют объемную зону совпадения и менее выраженную зону расхождений, соотношение которых подтверждает закономерность распределения универсальных (социокультурных параметров участников дискурса, универсальности норм письменной речи и текстопостроения) и дифференциальных признаков в текстах политической сферы. Величина зоны расхождения гендерных признаков различна для групп анализируемых единиц, однако является устойчивым и объективным показателем специфики «мужских» и «женских» текстов.

\section{Индексы «мужских» иженских» текстов на примере использования сочинительных союзов}

"Male" and "female" text indices examplified by the use of coordinative conjunctions

\begin{tabular}{|l|c|c|c|c|}
\hline \multicolumn{1}{|c|}{ Слово } & $\begin{array}{c}\text { Число вхо- } \\
\text { ждений М }\end{array}$ & Индекс М & $\begin{array}{c}\text { Число вхо- } \\
\text { ждений Ж }\end{array}$ & Индекс Ж \\
\hline и & 186069 & 0.036065 & 164417 & 0.036124 \\
\hline да & 5039 & 0.000976 & 3799 & 0.000834 \\
\hline также & 3153 & 0.000611 & 3979 & 0.000874 \\
\hline тоже & 2705 & 0.000524 & 3122 & 0.000685 \\
\hline или & 12309 & 0.002385 & 8638 & 0.001897 \\
\hline a & 38776 & 0.007515 & 33992 & 0.007468 \\
\hline но & 28501 & 0.005524 & 22167 & 0.004870 \\
\hline зато & 1435 & 0.000278 & 734 & 0.000161 \\
\hline однако & 4074 & 0.000789 & 3811 & 0.000837 \\
\hline притом & 144 & 0.000027 & 72 & 0.000015 \\
\hline причем & 1649 & 0.000319 & 1272 & 0.000279 \\
\hline то есть & 2896 & 0.000561 & 2379 & 0.000522 \\
\hline либо & 2583 & 0.000500 & 1917 & 0.000421 \\
\hline
\end{tabular}


С.В. Ионова, И.В. Огорелков. Речевая диагностика личности по гендерному признаку в автороведении

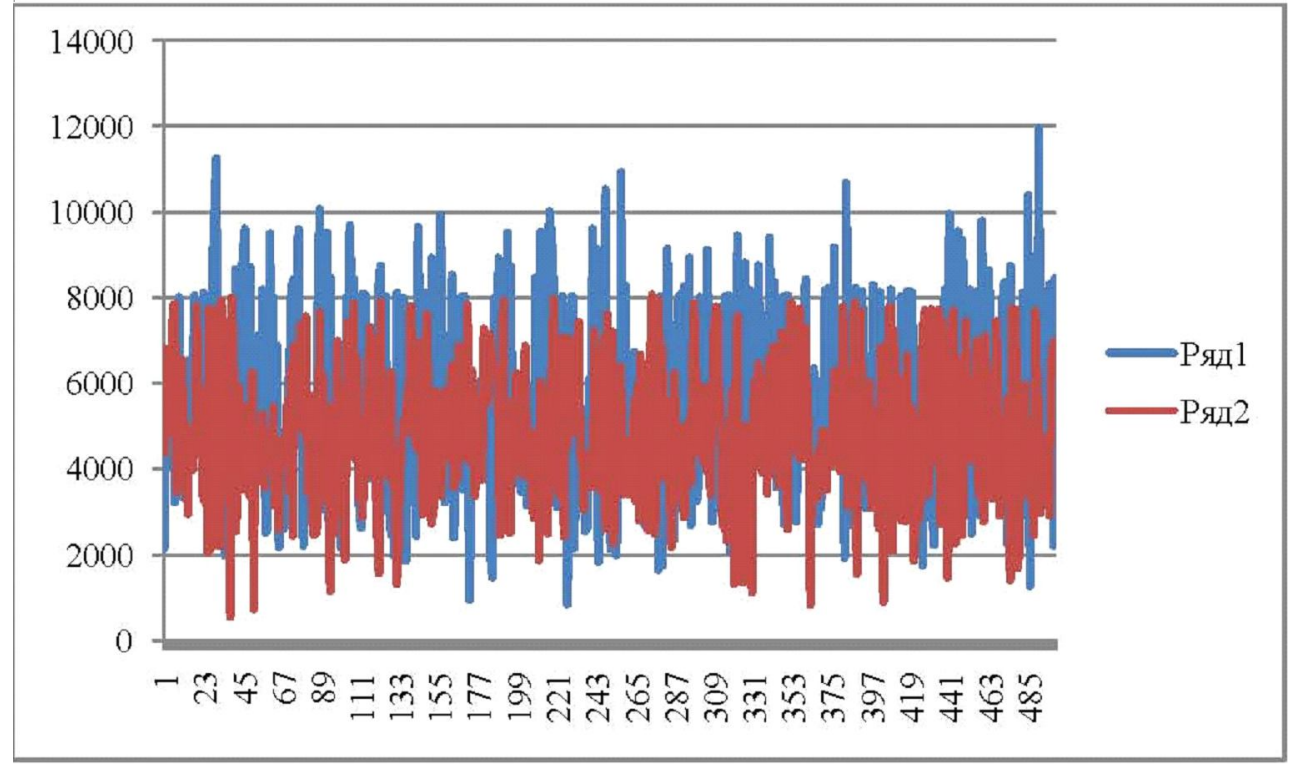

Рис. 1. Квантитативные характеристики союза но

Fig. 1. Quantitative characteristic of conjunction "но”

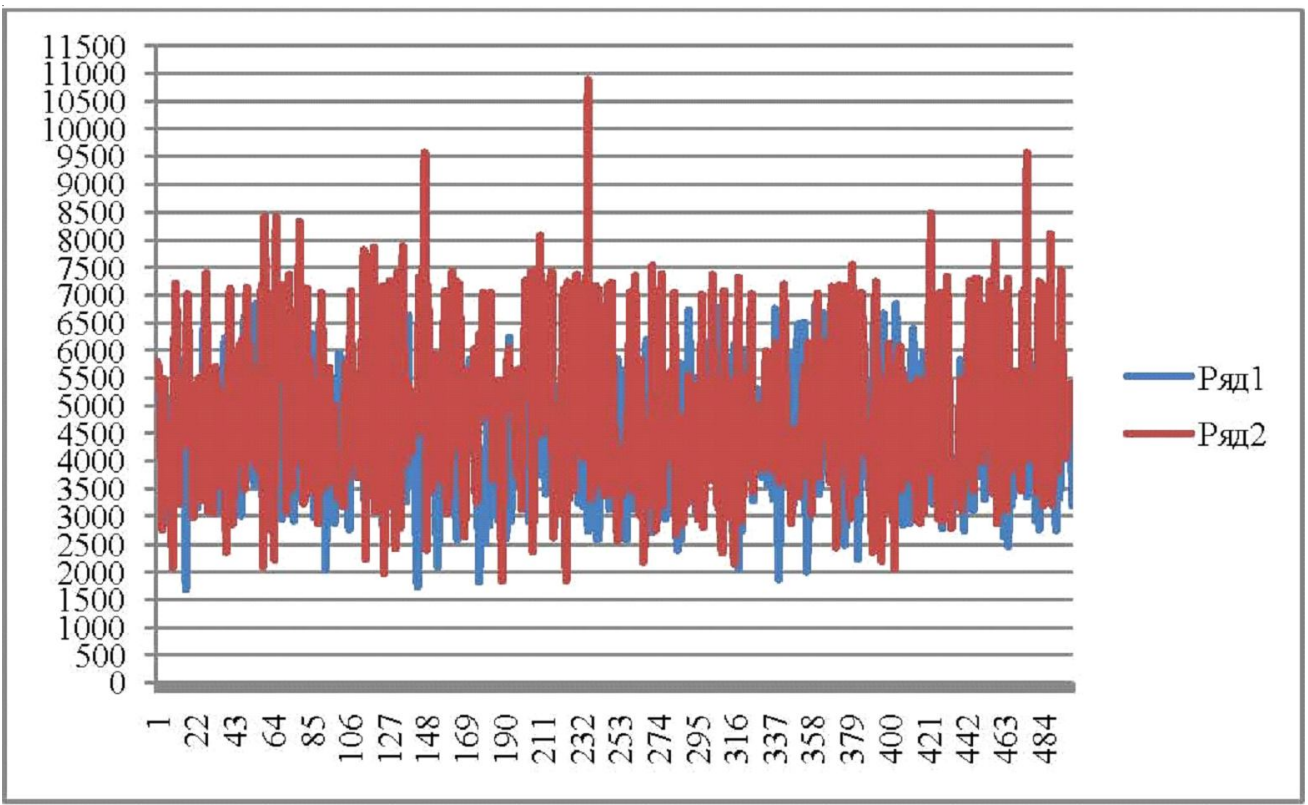

Рис. 2. Квантитативные характеристики предлога из

Fig. 2. Quantitative characteristic of prepozition “ $и з$ ”

При оценке пригодности объекта для проведения автороведческого исследования на основе предложенной методики следует учитывать ряд требований: а) текст документа должен быть представлен целиком (рассматриваться как цельный, завершенный); б) объем текста исследуемого документа должен составлять не менее 8000 словоформ для его анализа по критериям устойчивости и полноты свойств речемыслительного навы- ка; в) в тексте не должно быть элементов корректуры, редактуры, дописывания другим лицом (другими лицами); г) текст должен соответствовать стилю, жанру и тематике политического дискурса.

Повышение надежности результатов применения квантитативной модели гендера, выявленной в результате анализа частотности употребления определенных лексико-грамматических классов слов, предполагает ее со- 
четание с традиционной лингвистической моделью, включающей анализ языковых, речевых, текстовых, смысловых, психолингвистических и социальных характеристик текстов [Рубцова, Ермолова, Огорелков, 2008].

Полученные результаты являются релевантными для текстов, написанных на русском языке с учетом особенностей русской политической и речевой культуры.

\section{Выводы}

Применение разработанного нами квантитативного анализа письменных политических текстов на основе семантически независимых единиц показал, что данный метод не противоречит существующим лингвистическим подходам к анализу гендерных признаков авторов текстов и при этом научно обосновывает возможность их диагностики с опорой на неявные лингвистические признаки, впервые введенные в научный оборот и ранее не использованные в гендерных исследованиях. Сочетание различных подходов к решению этой диагностической задачи (качественного и количественного анализа материала, применение исследования частотности изучаемых единиц, их синтагматических, парадигматических и ассоциативных связей) должно значительно повысить верифицируемость полученных данных о гендерной принадлежности автора письменного русскоязычного текста политического дискурса в ходе проведения судебных автороведческих экспертиз.

Указанный подход не тождествен исследованиям в области изучения идиостилевых характеристик автора и идентификации индивидуальных параметров речи. При диагностировании следует говорить об устойчивых, регулярных, сверхличностных признаках, позволяющих выявлять черты неопределенной личности, относящейся к одному из типов языковых личностей. Перспективной задачей современной диагностической лингвистики должно стать выделение скрытой и неосознаваемой части речевой деятельности, автоматизированных навыков и стереотипных речевых проявлений, поиск и исследование новых единиц анализа, совершенствование методов их изучения.

Потребность лингвистической науки и практики в совершенствовании методов оп- ределяет необходимость продолжения исследований гендерных параметров письменной речи, которые являются востребованными не только в криминалистике, но и иных сферах деятельности человека. Разыскания российских ученых должны изменить положение в области гендерной лингвистики, где исторически доминируют работы американских и западноевропейских исследователей, демонстрирующих особенности их языков и культур, манифестирующих свойственные им концепты мужественности и женственности.

Разработка новых и уточнение существующих методов диагностики речи, проведения автороведческих исследований имеет не только прикладное значение, но и обогащает лингвистическую теорию, стимулируя развитие всех ее направлений, расширение инструментария и объектов изучения.

\section{СПИСОК ЛИТЕРАТУРЫ}

Вепрева И. Т., 2010. «Грамматический вирус» женскости на фоне тенденции к аналитизму в современном русском языке // Русский язык и литература в международном образовательном пространстве: современное состояние и перспективы : Материалы II Междунар. конф. (г. Гранада, 8-10 сентября 2010 г.). Мадрид : Rubinos-1860. C. 74-78.

Вул С. М., Мартынюк А. П., 1987. Теоретические предпосылки диагностирования половой принадлежности автора документа // Современное состояние и перспективы развития традиционных видов криминалистической экспертизы : сб. науч. тр. М. : Изд-во ВНИИСЭ. С. 105-112.

Гомон Т. В.,1990. Исследование документов с деформированной внутренней структурой : дис. ... канд. юрид. наук. М. 183 с.

Горошко Е. И., 1998. Специфика ассоциативного сознания некоторых групп русскоязычного населения Украины // Языковое сознание: формирование и функционирование / отв. ред. д-р филол. наук Н. В. Уфимцева. М. : Ин-т языкознания РАН. С. 186-200.

Горошко Е. И., 1999. Пол, гендер, язык // Женщина. Гендер. Культура / ред. : 3. А. Хоткина, Н. Л. Пушкарева, Е. И. Трофимова. М. : Издво МЦГИ. С. 98-110.

Горошко Е. И., Павлова Л. В., 2015. Лингвистика новых медиа как один из вызовов лингвистической традиции прошлого // Вопросы психолингвистики. № 24. С. 43-54. 
Гречушникова Т. В., 2000. Феминистская лингвистика и авторское словотворчество: в поисках языковой самореализации женщин // Женские и гендерные исследования в Тверском государственном университете. Тверь : Твер. гос. ун-т. С. 68-85.

Григорян А. А., 2004. Состояние и перспективы гендерной лингвистики на Западе в конце XX начале XXI веков. Иваново : Иван. гос. ун-т. $290 \mathrm{c}$.

Жельвис В. И., 1997. Поле брани: сквернословие как социальная проблема. М. : Ладомир. 328 с.

Земская Е. А., Китайгородская М. В., Розанова Н. Н., 1993. Особенности мужской и женской речи // Русский язык в его функционировании. Коммуникативно-прагматический аспект / отв. ред. Е. А. Земская, Д. Н. Шмелев. М. : Наука. С. 90-136.

Иванченко Г. В., 2008. Комплексная гуманитарная экспертиза: методология и смысл. М. : Смысл. $135 \mathrm{c}$.

Ионова С. В., 2014. Деривация в сфере текстов: от комического до криминального // Studia Linguistica. № XXIII. C. 253-262.

Кирилина А. В., 1999. Гендер: лингвистические аспекты. М. : Изд-во Ин-та социологии РАН. $189 \mathrm{c}$.

Кирилина А. В., 2015. Гендерные репрезентации в России начала третьего тысячелетия // Когнитивные исследования языка. № 21. С. 570-574.

Кирилина А. В., Томская М. В., 2005. Лингвистические гендерные исследования // Отечественные записки. № 2 (23). С. 22-43.

Комплексная методика производства автороведческих экспертиз : метод. рек., 2007 / И. И. Рубцова, Е. И. Ермолова, А. И. Безрукова, И. В. Огорелков, М. П. Захаров. М. : ЭКЦ МВД России. $250 \mathrm{c}$.

Крейдлин Г. Е., 2003. Мужчины и женщины в невербальной коммуникации: культурно-универсальные и культурно-специфические особенности невербального коммуникативного поведения // Гендер: язык, культура, коммуникация : Материалы Третьей междунар. конф. (г. Москва, 27-28 ноября 2003 г.). М. : Изд-во МГЛУ. С. 67-68.

Криминалистика: проблемы, тенденции, перспективы, 1987 / под ред. Р. С. Белкина. М. : Юрид. лит. $270 \mathrm{c}$.

Кубрякова Е. С., 1978. Части речи в ономасиологическом освещении. М. : Наука. 115 с.

Кузниченко Л. В., 2004. Экспертиза письменной речи: установление классификационных характеристик автора документа // Криминалистика и судебная экспертиза : сб. науч. работ. Киев. Вып. 52. С. 65-72.
Куницына Е. В., 2011. Гендерная маркированность политического дискурса: языковой и речевой аспекты : дис. ... канд. филол. наук. Ставрополь. 249 с.

Мартынюк А. П., Землянский П. Н., 1994. Речевое поведение мужчин и женщин в малых группах // Язык. Сознание. Этнос. Культура. М. : Ин-т языкознания РАН. С. 134-135.

Методические рекомендации по проведению автороведческих экспертиз по материалам интернет-переписки, 2015 / Т. И. Голощапова, Е. А. Красовская, М. А. Девятова, И. В. Огорелков. М. : ЭКУ 9 Департамента ФСКН. 180 с.

Ощепкова Е. С., 2003. Идентификация пола автора по письменному тексту: лексико-грамматический аспект : дис. ... канд. филол. наук. М. 154 с.

Потапова Р. К., 2001. Сексолект как объект исследования в криминалистике // Гендер: Язык, Культура, Коммуникация : докл. Перв. междунар. конф. (г. Москва, 25-26 ноября 1999 г.). М. : Изд-во МГЛУ. С. 302-313.

Рубцова И. И., Ермолова Е. И., Огорелков И. В., 2008. Определение пола и возраста автора анонимного текста по письменной речи : метод. рек. М. : ЭКЦ МВД России. 220 c.

Сепир Э., 1993. Избранные труды по языкознанию и культурологии. М. : Прогресс. 656 с.

Сиротинина О. Б., 1996. Человек и его язык // Вопросы стилистики. Саратов : Изд-во Сарат. унта. Вып. 26. С. 3-8.

Словарь языка Достоевского. Лексический строй идиолекта, 2001 / под ред. Ю. Н. Караулова. М. : Изд-во Ин-та рус. яз. им. В.В. Виноградова : Азбуковник. Вып. 1.508 с.

Словарь языка Пушкина : в 4 т., 2001 / под ред. В. В. Виноградова. М. : Азбуковник. Т. 1. 982 с.; Т. 2.1088 с.; Т. 3.1296 с.; Т. 4.1232 с.

Степанов Ю. С., 1997. Константы. Словарь русской культуры: Опыт исследования. М. : Языки русской культуры. 824 с.

Стернин И. А., 2001. Общение с мужчинами и женщинами. Воронеж : Истоки. 35 с.

Табурова С. К., 2000. Эмоции в речи депутатов бундестага: мужские и женские преференции // Гендер как интрига познания : сб. ст. М. : Рудомино. С. 186-191.

Уфимцева Н. В., 2018. Язык, глобализация и идентичность // Русский язык в поликультурном мире : сб. науч. ст. II Междунар. симпозиума (г. Ялта, 8-12 июня 2018 г.). Симферополь : Ареал. С. 3-10.

Филлмор Ч., 1981. Дело о падеже // Новое в зарубежной лингвистике. М. : Прогресс. Вып. 10. С. 369-496.

Чернявская В. Е., 2001. Дискурс как объект лингвистических исследований // Текст и дискурс. 
Проблемы экономического дискурса : сб. науч. ст. СПб. : Изд-во СПб ГУЭФ. С. 11-22.

Чудинов А. П., 2012. Дискурсивные характеристики политической коммуникации // Политическая лингвистика. № 2 (40). С. 53-59.

Connell R. W., 1993. The Big Picture: Masculinities in Recent World History // Theory and Society. Vol. 22, no. 5. P. 597-623.

Ervin-Tripp S. M., 1972. On Sociolinguistics Rules: Alternation and Concurrence // Directions in Sociolinguistics / ed by J. J. Gumperz, D. Hymes. N. Y. : Holt, Rinehart and Winston. P. 213-250.

Fairclough N., 2003. Analysing Discourse: Textual Analysis for Social Research. L. ; N. Y. : Routledge. 270 p.

Jespersen O., 1998. The Woman // The Feminist Critique of Language: A Reader. L. ; N. Y. : Routledge. P. 225-241.

Labov W., 1971. Variation in Language // The Learning of Language. National Council of Teachers of English / ed by E. R. Carrol. N. Y. : AppletonCentury-Crofts. P. 187-221.

Lakoff R.,1973. Language and Women's Place // Language in Society. № 2. P. 45-79.

Milroy J., Milroy L., 1985. Authority in Language. Investigating Language Prescription and Standardisation. L. : Routledge \& Kegan Paul. $189 \mathrm{p}$.

Ochs E., 1979. Planned and Unplanned Discourse // Syntax and Semantics 12: Discourse and Syntax / ed by T. Givyn. N. Y. : Academic Press. P. 51-80.

Perloff R. M., 1998. Political Communication: Politics, Press and Public in America. Mahwah, NJ : Lawrence Erlbaum Associates. 492 p.

Pollack W. S., 1995. Deconstructing Dis-Identification: Returning Psychoanalitic Concepts of Male Development // Psychoanalysis and Psychotherapy. № 12. P. 30-45.

Rogoff I., Leer D. van, 1993. Afterthoughts. A Dossier on Masculinities // Theory and Sosiety. Vol. 22, no. 5. P. 739-762.

Trudgill P., 1972. Sex, Covert Prestige, and Linguistic Change in the Urban British English of Norwich // Language in Society. Vol. 1, iss. 2. P. 179-195.

Wann ist der Mann ein Mann? Zur Geschichte der Männlichkeit?, 1997 / hrgs. von W. Erhart, B. Hermann. Stuttgart-Weimar : Metzler. 398 p.

\section{REFERENCES}

Vepreva I.T., 2010. «Grammaticheskiy virus» zhenskosti na fone tendentsii $\mathrm{k}$ analitizmu $\mathrm{v}$ sovremennom russkom yazyke ["Grammatical Virus" of Femininity Against the Background of the Trend Towards Analyticism in Mmodern Russian]. Russkiy yazyk i literatura $v$ mezhdunarodnom obrazovatelnom prostranstve: sovremennoe sostoyanie $i$ perspektivy: Materialy II Mezhdunar. konf. (g. Granada, 810 sentyabrya 2010 g.) [Russian Language and Literature in the International Educational Space: Current State and Prospects. Proceedings of the $2^{\text {nd }}$ International Conference (Granada, September 8-10, 2010)]. Madrid, Rubinos-1860 Publ., pp. 74-78.

Vul S.M., Martynyuk A.P., 1987. Teoreticheskie predposylki diagnostirovaniya polovoy prinadlezhnosti avtora dokumenta [Theoretical Prerequisites for Diagnosing the Gender of the Author of the Document]. Sovremennoe sostoyanie $i$ perspektivy razvitiya traditsionnykh vidov kriminalisticheskoy ekspertizy: sb. nauch. tr. [Current State and Prospects of Development of Traditional Types of Forensic Examination]. Moscow, Izd-vo VNIISE, pp. 105-112.

Gomon T.V., 1990. Issledovanie dokumentov $s$ deformirovannoy vnutrenney strukturoy: dis.... kand. yurid. nauk [Study of Documents with Deformed Internal Structure. Cand. jur. sci. diss]. Moscow. 183 p.

Goroshko E.I., 1998. Spetsifika assotsiativnogo soznaniya nekotorykh grupp russkoyazychnogo naseleniya Ukrainy [Specificity of Associative Consciousness of Some Groups of the RussianSpeaking Population of Ukraine]. Ufimtseva N.V., ed. Yazykovoe soznanie: formirovanie $i$ funktsionirovanie [Language Consciousness. Formation and Functioning]. Moscow, Institut yazykoznaniya RAN, pp. 186-200.

Goroshko E.I., 1999. Pol, gender, yazyk [Sex, Gender, Language]. Khotkina Z.A., Pushkareva N.L., Trofimova E.I., eds. Zhenshchina. Gender. Kultura [Woman. Gender. Culture]. Moscow, Izd-vo MTsGI, pp. 98-110.

Goroshko E.I., Pavlova L.V., 2015. Lingvistika novykh media kak odin iz vyzovov lingvisticheskoy traditsii proshlogo [Linguistics of New Media as a Challenge to Traditional Linguistics of the Past]. Voprosy psikholingvistiki [Journal of Psycholinguistics], no. 24, pp. 43-54.

Grechushnikova T.V., 2000. Feministskaya lingvistika i avtorskoe slovotvorchestvo: v poiskakh yazykovoy samorealizatsii zhenshchin [Feminist Linguistics and Author's Word Creation]. Zhenskie i gendernye issledovaniya $v$ Tverskom gosudarstvennom universitete [Women's and Gender Studies at Tver State University]. Tver, Tverskoy gosudarstvennyy universitet, pp. 68-85. 
Grigoryan A.A., 2004. Sostoyanie i perspektivy gendernoy lingvistiki na Zapade v kontse $X X-$ nachale XXI vekov [State and Prospects of Gender Linguistics in the West in the Late $20^{\text {th }}$ Early $21^{\text {st }}$ Centuries]. Ivanovo, Ivanovskiy gosudarstvennyy universitet. $290 \mathrm{p}$.

Zhelvis V.I., 1997. Pole brani: skvernoslovie kak sotsialnaya problema [Battlefield of Curses: Profanity as a Social Problem]. Moscow, Ladomir Publ. 328 p.

Zemskaya E.A., Kitaygorodskaya M.V., Rozanova N.N., 1993. Osobennosti muzhskoy i zhenskoy rechi [Features of Male and Female Speech]. Zemskaya E.A., Shmelev D.N., eds. Russkiy yazyk v ego funktsionirovanii. Kommunikativnopragmaticheskiy aspekt [Russian Language in Its Functioning. Communicative and Pragmatic Aspect]. Moscow, Nauka Publ., pp. 90-136.

Ivanchenko G.V., 2008. Kompleksnaya gumanitarnaya ekspertiza: metodologiya i smysl [Comprehensive Humanitarian Expertise: Methodology and Meaning]. Moscow, Smysl Publ. 135 p.

Ionova S.V., 2014. Derivatsiya v sfere tekstov: ot komicheskogo do kriminalnogo [Derivation in the Sphere of Texts: From Comic to Criminal]. Studia Linguistica, no. XXIII, pp. 253-262.

Kirilina A.V., 1999. Gender: lingvisticheskie aspekty [Gender: Linguistic Aspects]. Moscow, Izd-vo Instituta sotsiologii RAN. 189 p.

Kirilina A.V., 2015. Gendernye reprezentatsii v Rossii nachala tretyego tysyacheletiya [Russian Gender Representations at the Beginning of the Third Millennium]. Kognitivnye issledovaniya yazyka [Cognitive Studies of Language], no. 21, pp. 570-574.

Kirilina A.V., Tomskaya M.V., 2005. Lingvisticheskie gendernye issledovaniya [Linguistic Gender Studies]. Otechestvennye zapiski, no. 2 (23), pp. 22-43.

Rubcova I.I., Ermolova E.I., Bezrukova A.I., Ogorelkov I.V., Zakharov M.P., 2007. Kompleksnaya metodika proizvodstva avtorovedcheskikh ekspertiz: metod. rek. [Comprehensive Methodology for the Production of Automotive Expertise. Guidelines]. Moscow, EKTs MVD Rossii. $250 \mathrm{p}$.

Kreydlin G.E., 2003. Muzhchiny i zhenshchiny v neverbalnoy kommunikatsii: kulturnouniversalnye i kulturno-spetsificheskie osobennosti neverbalnogo kommunikativnogo povedeniya [Men and Women in Nonverbal Communication. Cultural-Universal and CulturalSpecific Features of Nonverbal Communicative Behavior]. Gender: yazyk, kultura, kommunikatsiya: Materialy Tretyey mezhdunar. konf. (g. Moskva, 27-28 noyabrya 2003 g.)
[Gender: Language, Culture, Communication: Materials of the Third International Conference (Moscow, November 27-28, 2003).]. Moscow, Izd-vo MGLU, pp. 67-68.

Belkin R.S., ed., 1987. Kriminalistika: problemy, tendentsii, perspektivy [Criminalistics: Problems, Trends, Prospects]. Moscow, Yuridicheskaya literature Publ. 270 p.

Kubryakova E.S., 1978. Chasti rechi v onomasiologicheskom osveshchenii [Parts of Speech in Onomasiological Coverage]. Moscow, Nauka Publ. 115 p.

Kuznichenko L.V., 2004. Ekspertiza pismennoy rechi: ustanovlenie klassifikatsionnykh kharakteristik avtora dokumenta [Examination of Written Speech: Establishing the Classification Characteristics of the Author of the Document]. Kriminalistika $i$ sudebnaya ekspertiza: sb. nauch. rabot [Forensics and Forensic Analysis. Collection of Scientific Works]. Kiev, iss. 52, pp. 65-72.

Kunitsyna E.V., 2011. Gendernaya markirovannost politicheskogo diskursa: yazykovoy i rechevoy aspekty: dis. ... kand. filol. nauk [Gender Marking of Political Discourse: Language and Speech Aspects. Cand. philol. sci. diss.]. Stavropol. 249 p.

Martynyuk A.P., Zemlyanskiy P.N., 1994. Rechevoe povedenie muzhchin i zhenshchin $\mathrm{v}$ malykh gruppakh [Speech Behavior of Men and Women in Small Groups]. Yazyk. Soznanie. Etnos. Kultura [Language. Consciousness. Ethnos. Culture]. Moscow, Institut yazykoznaniya RAN, pp. 134-135.

Goloshchapova T.I., Krasovskaya E.A., Devyatova M.A., Ogorelkov I.V., 2015. Metodicheskie rekomendatsii po provedeniyu avtorovedcheskikh ekspertiz po materialam internet-perepiski [Guidelines for Conducting Expert Examinations Based on Internet Correspondence]. Moscow, EKU 9 Departamenta FSKN. 180 p.

Oshchepkova E.S., 2003. Identifikatsiya pola avtora po pismennomu tekstu: leksikogrammaticheskiy aspekt: dis. ... kand. filol. nauk [Identification of the Author's Gender by Written Text: Lexical and Grammatical Aspect. Cand. philol. sci. diss.]. Moscow. 154 p.

Potapova R.K., 2001. Seksolekt kak obyekt issledovaniya $\mathrm{v}$ kriminalistike [Sexoct as an Object of Study in Forensic Science]. Gender: Yazyk, Kultura, Kommunikatsiya: Dokl. Perv. mezhdunar. konf. (g. Moskva, 25-26 noyabrya 1999 g.) [Gender: Language, Culture, Communication. The Proceedings of the $1^{\text {st }}$ International Conference (Moscow, November 25-26, 1999)]. Moscow, Izdvo MGLU, pp. 302-313. 
Rubtsova I.I., Ermolova E.I., Ogorelkov I.V., 2008. Opredelenie pola $i$ vozrasta avtora anonimnogo teksta po pismennoy rechii: metod. rek. [Determining the Gender and Age of the Author of an Anonymous Text in Writing: Guidelines]. Moscow, EKTs MVD Rossii. 220 p.

Sepir E., 1993. Izbrannye trudy po yazykoznaniyu $i$ kulturologii [Selected Works on Linguistics and Cultural Studies]. Moscow, Progress Publ. 656 p.

Sirotinina O.B., 1996. Chelovek i ego yazyk [Man and His Language]. Voprosy stilistiki [Issues of Stylistics]. Saratov, Izd-vo Saratovskogo universiteta. Iss. 26, pp. 3-8.

Karaulov Yu.N., ed., 2001. Slovaryazyka Dostoevskogo. Leksicheskiy stroy idiolekta [Dictionary of the Language of Dostoyevsky. Lexical Structure of an Idiolect]. Moscow, Izd-vo Instituta russkogo yazyka im. V.V. Vinogradova, Azbukovnik Publ., iss. $1.508 \mathrm{p}$.

Vinogradov V.V., ed., 2000. Slovar yazyka Pushkina: $v 4 t$ [Dictionary of Language of Pushkin]. Moscow, Azbukovnik Publ., vol. 1. 982 p.; vol. 2. 1088 p.; vol. 3.1296 p.; vol. 4. 1232 p.

Stepanov Yu.S., 1997. Konstanty. Slovar russkoy kultury: Opyt issledovaniya [Constants. Dictionary of Russian Culture: Research Experience]. Moscow, Yazyki russkoy kultury Publ. 824 p.

Sternin I.A., 2001. Obshchenie s muzhchinami $i$ zhenshchinami [Communication with Men and Women]. Voronezh, Istoki Publ. 35 p.

Taburova S.K., 2000. Emotsii v rechi deputatov bundestaga: muzhskie i zhenskie preferentsii [Emotions in the Speech of Bundestag Deputies: Male and Female Preferences]. Gender kak intriga poznaniya: sb. st. [Gender as Intrigue of Cognition. Collected Articles]. Moscow, Rudomino Publ., pp. 186-191.

Ufimtseva N.V., 2018. Yazyk, globalizatsiya i identichnost [Language, Globalization and Identity]. Russkiy yazyk $v$ polikulturnom mire: sb. nauch. st. II Mezhdunar. simpoziuma (g. Yalta, 8-12 iyunya 2018 g.) [Russian in a Multicultural World. Collection of Scientific Articles of the $2^{\text {nd }}$ International Symposium (Yalta, June 8-12, 2018). Simferopol, Areal, pp. 3-10.

Fillmor Ch., 1981. Delo o padezhe [Case of the Case]. Novoe $v$ zarubezhnoy lingvistike [New in Foreign Linguistics]. Moscow, Progress Publ., iss. 10, pp. 369-496.

Chernyavskaya V.E., 2001. Diskurs kak obyekt lingvisticheskikh issledovaniy [Discourse as an Object of Linguistic Research]. Tekst i diskurs.
Problemy ekonomicheskogo diskursa: sb. nauch. st. [Text and Discourse. Problems of Economic Discourse. Collection of Scientific Articles]. Saint Petersburg, Izd-vo SPb GUEF, pp. 11-22.

Chudinov A.P., 2012. Diskursivnye kharakteristiki politicheskoy kommunikatsii [Discoursive Characteristics of Political Communication]. Politicheskaya lingvistika [Political Linguistics], no. 2 (40), pp. 53-59.

Connell R. W., 1993. The Big Picture: Masculinities in Recent World History. Theory and Society, vol. 22, no. 5, pp. 597-623.

Ervin-Tripp S.M., 1972. On Sociolinguistics Rules: Alternation and Concurrence. Gumperz J.J., Hymes D., eds. Directions in Sociolinguistics. New York, Holt, Rinehart and Winston, pp. 213-250.

Fairclough N., 2003. Analysing Discourse: Textual Analysis for Social Research. London, New York, Routledge. $270 \mathrm{p}$.

Jespersen O., 1998. The Woman. The Feminist Critique of Language: A Reader. London, New York, Routledge, pp. 225-241.

Labov W., 1971. Variation in Language. Carrol E.R., ed. The Learning of Language. National Council of Teachers of English. New York, Appleton-Century-Crofts, pp. 187-221.

Lakoff R., 1973. Language and Women's Place. Language in Society, no. 2, pp. 45-79.

Milroy J., Milroy L., 1985. Authority in Language. Investigating Language Prescription and Standardisation. London, Routledge \& Kegan Paul. 189 p.

Ochs E., 1979. Planned and Unplanned Discourse. Givyn T., ed. Syntax and Semantics 12: Discourse and Syntax. New York, Academic Press, pp. 51-80.

Perloff R.M., 1998. Political Communication: Politics, Press and Public in America. Mahwah, Lawrence Erlbaum Associates. 492 p.

Pollack W.S., 1995. Deconstructing Dis-Identification: Returning Psychoanalitic Concepts of Male Development. Psychoanalysis and Psychotherapy, no. 12, pp. 30-45.

Rogoff I., Leer D. van, 1993. Afterthoughts. A Dossier on Masculinities. Theory and Sosiety, vol. 22, no. 5, pp. 739-762.

Trudgill P., 1972. Sex, Covert Prestige, and Linguistic Change in the Urban British English of Norwich. Language in Society, vol. 1, iss. 2, pp. 179-195.

Erhart W., Hermann B., Hrsg., 1997. Wann ist der Mann ein Mann? Zur Geschichte der Männlichkeit? Stuttgart-Weimar, Metzler. 398 p. 
С.В. Ионова, И.В. Огорелков. Речевая диагностика личности по гендерному признаку в автороведении

\section{Information About the Authors}

Svetlana V. Ionova, Doctor of Sciences (Philology), Professor, Department of General and Russian Linguistics, Pushkin State Russian Language Institute, Akademika Volgina St., 6, 117485 Moscow, Russia; Chief Expert, Moscow Research Center, Nizhnyaya Syromyatnicheskaya St., 5, Bld. 3, 105120 Moscow, Russia, sionova@mail.ru, https://orcid.org/0000-0001-6361-741X

Igor' V. Ogorelkov, Head of the Department of Linguistic Expertise and Research, Moscow Research Center, Nizhnyaya Syromyatnicheskaya St., 5, Bld. 3, 105120 Moscow, Russia, ogorelkov.69@mail.ru, https://orcid.org/0000-0001-5116-3975

\section{Информация об авторах}

Светлана Валентиновна Ионова, доктор филологических наук, профессор кафедры общего и русского языкознания, Государственный институт русского языка им. А.С. Пушкина, ул. Академика Волгина, 6, 117485 г. Москва, Россия; главный эксперт, Московский исследовательский центр, ул. Нижняя Сыромятническая, 5, стр. 3, 105120 г. Москва, Россия, sionova@mail.ru, https://orcid.org/0000-0001-6361-741X

Игорь Витальевич Огорелков, начальник отдела лингвистических экспертиз и исследований, Московский исследовательский центр, ул. Нижняя Сыромятническая, 5, стр. 3, 105120 г. Москва, Россия, ogorelkov.69@mail.ru, https://orcid.org/0000-0001-5116-3975 